Mandujano Rodríguez.M.G. (2019). "Integration of Historic Building Information Modeling and Conventional Valuation Approaches for Managing Cultural Heritage Sites." In: Proc. 27th Annual Conference of the International. Group for Lean Construction (IGLC), Pasquire C. and Hamzeh F.R. (ed.), Dublin, Ireland, pp. 1433-1444. DOI: https://doi.org/10.24928/2019/0253. Available at: 〈www.iglc.net>.

\title{
INTEGRATION OF HISTORIC BUILDING INFORMATION MODELING AND VALUATION APPROACHES FOR MANAGING CULTURAL HERITAGE SITES
}

\author{
María Guadalupe Mandujano Rodríguez ${ }^{1}$
}

\begin{abstract}
In this study, a methodology for quantifying the historical value of the Cathedral of Christ the King, in the municipality of Huejutla de Reyes, Hidalgo, Mexico, was developed through application of historic building information modeling (HBIM) and conventional valuation methods. Despite many studies having been undertaken around the world, there remains a gap in that elucidating and unifying the relationship between HBIM and valuation is still difficult. The methodology developed in this study combined and used information captured via a Leica ScanStation C10 laser scanner, a drone, and a $360^{\circ}$ camera. Various software programs were then used to combine the images with the scan data. HBIM facilitated automatic and accurate quantification of the amount of materials used to build the cathedral. A significant finding was that the use of HBIM enables a valuation to be obtained immediately. While the results must be regarded as being exploratory, they provide interesting insights into the synergy between HBIM and historical valuation. Another critical point is that this is, to the best of our knowledge, the first study to link HBIM with a valuation.
\end{abstract}

\section{KEYWORDS}

Cultural heritage, historic building information modelling (HBIM), valuation, collaboration, commitment.

\section{INTRODUCTION}

The building information modeling (BIM) methodology, defined as "the use of virtual, multidisciplinary models of design and construction projects, including product models, processes and organizations, to support explicit and public business objectives," is one aspect of virtual design and construction (VDC) (Kunz and Fischer 2009; Mandujano et al. 2017). BIM provides a reliable basis for decision-making and acts as a platform for automated analysis that can assist with planning, design processes, construction management, and operation/maintenance activities (Alarcón et al. 2013). Historic building information modeling (HBIM) is proposed as a new means of modeling historic structures;

1 Corresponding author. CEO, MARO Consulting, Huejutla de Reyes, Hidalgo, Mexico. E-mail: info@maroconsulting.mx 
the HBIM process begins with remote collection of survey data using a terrestrial laser scanner combined with digital cameras. Various software programs are then used to combine the image and scan data (Murphy et al. 2009). The HBIM process involves a reverse-engineering solution whereby parametric objects representing architectural elements are mapped onto laser scans or photogrammetric survey data (Dore and Murphy 2012). On the other hand, valuation is a sustainable estimate of the value of a property. As it is only an estimate, the merit of any value judgment depends on the skill, experience, and ability of the person doing it (The International Valuation Standards Committee 2006). Despite many studies having been undertaken around the world (Herrero Prieto and Bedate Centeno 2000; Melstrom 2013; Pérez et al. 1996; Poor and Smith 2004; Riera et al. 1994; Tourkolias et al. 2015), elucidating and unifying the relationship between HBIM and valuation is still difficult. Annually, approximately 200,000 tourists visit the municipality of Huejutla de Reyes, Hidalgo (Departamento de Turismo 2017). These tourists walk its picturesque streets, enjoy the cuisine, and visit the various sites around the region. One of the most well-known sites is Cathedral of Christ the King. Fig. 1 shows an image of the cathedral immediately prior to its completion circa $1545 \mathrm{CE}$.

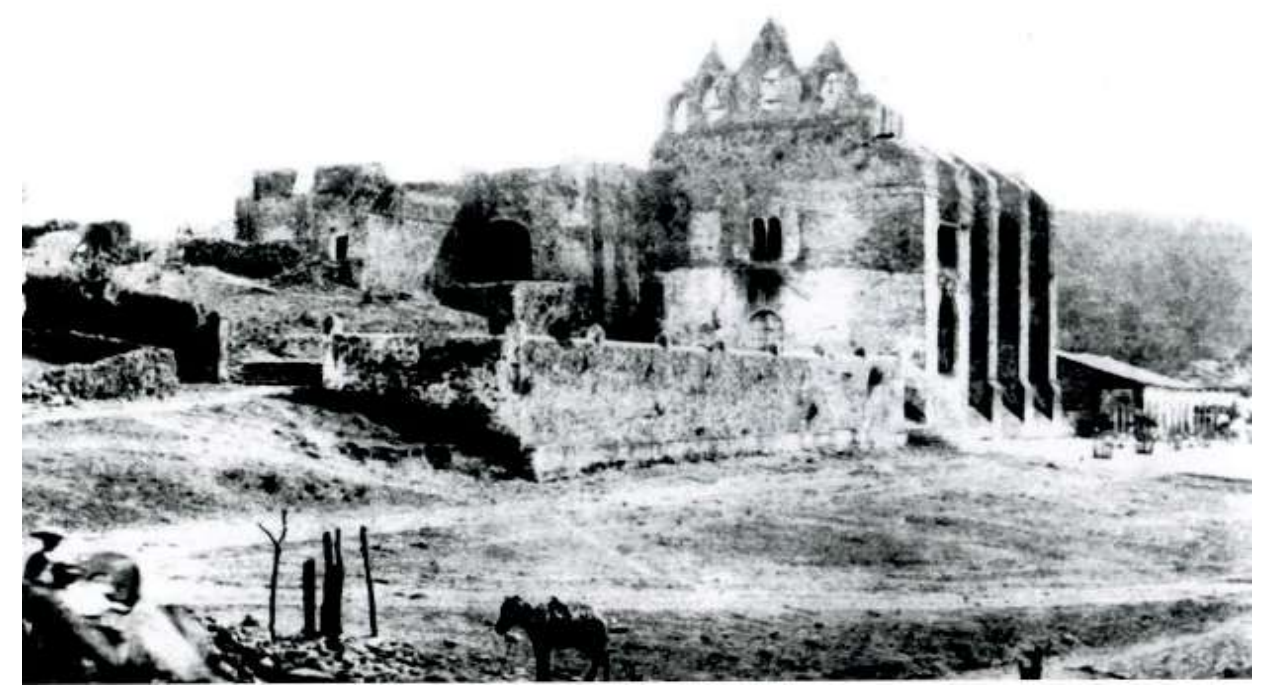

Figure 1: Construction of Cathedral of Christ the King, circa 1545 CE. Craftsmen transported materials to the work site in various ways.

The remainder of this paper is organized as follows. Section 2 explains the proposed methodology. Section 3 describes the state of the art and the data collection process. Section 4 presents the analysis of the data. Section 5 outlines the results of the research. Section 6 explains the significance of the results. Section 7 presents concluding remarks.

\section{RESEARCH AIM AND PROPOSED METHODOLOGY}

This study developed a methodology for quantifying the historical value of the Cathedral of Christ the King, by historic building information modeling (HBIM) and conventional valuation techniques. To achieve this, the following specific objectives were set: 
- Develop a methodology using HBIM and conventional valuation approaches.

- Identify the relative importance and relationship existing between HBIM and conventional valuation approaches.

- Whether or not the work enabled you to draw conclusions about the hypotheses, or further work is needed?

Fig. 2 depicts the proposed methodology.

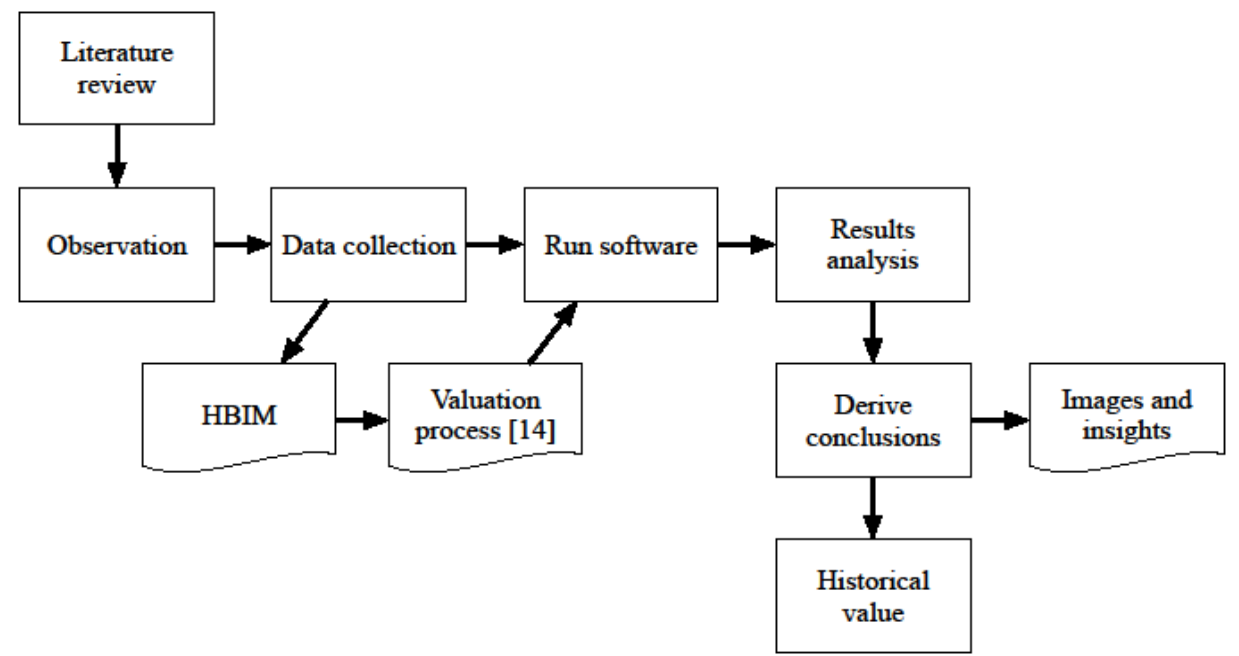

Figure 2: Proposed methodology. The present study set out to realize each step of the proposed methodology.

Different sectors such as municipalities, and the state and federal governments, will have their own methodologies that will give them more confidence in their decision-making. Decision-making is based on hard data acquired through an information, knowledge, experience, analysis, and judgment-based process. Nevertheless, organizations such as the National Council for Culture and Arts (CONACULTA), National Institute of Anthropology and History (INAH), National Institute of Fine Arts (INBA), United Nations Educational, Scientific and Cultural Organization (UNESCO), and Ministry of Tourism (SECTUR), may revalue the Cathedral of Christ the King, assigning resources to its restoration or proposing a project to promote tourism in the region.

\section{STATE OF THE ART}

The complexity and difficulty associated with valuation of historical assets is rooted in the concepts of culture and cultural heritage. Culture is difficult to define and even harder to quantify (McLoughlin et al. 2007; Noonan 2003; Papandrea 1999; Throsby 1995). Since its inception in 1972, UNESCO has defined monuments as being groups of buildings and places that are of interest and which have relevance to civilization and culture, and which can, therefore, be classified as being part of the cultural heritage. Klamer and Zuidhof (1999), classified cultural heritage as both tangible and intangible. From an economic perspective, the assumption that cultural heritage is a public good and generates indirect 
effects has been agreed upon by several authors (Frey and Meier 2006; Johnson and Thomas 1998). Many studies have been carried out with the goal of determining the value of different historical and cultural patrimonies around the world (Bedate et al. 2004; Cameron 1992; Caulkins et al. 1986; Dilnessa 2014; Herrero Prieto and Bedate Centeno 2000; McLoughlin et al. 2007; Melstrom 2013; Nijkamp 2012; Noonan 2003; Nypan 2006; Parumog et al. 2003; Poor and Smith 2004; Tourkolias et al. 2015). Although only a few studies have addressed the value of BIM to the management and documentation of cultural monuments (Fai et al. 2011), BIM has exhibited considerable growth over the last decade in the cultural heritage field (Achille et al. 2016; Del Giudice and Osello 2013; Dore and Murphy 2012; Garagnani and Manferdini 2013). Architects, archaeologists, conservationists, and engineers regard BIM as a disruptive force that changes the way in which professionals document and manage a historical monument (Brusaporci 2015; Choi et al. 2010; Logothetis et al. 2015; Saygi et al. 2013). Arayici (2008), attempted the first application of BIM to "existing" buildings. The study focused on implementation of automated data acquisition and recognition of patterns, using data in a point cloud to represent volumetric (3D) data in the generation of a construction envelope. Other researchers further developed HBIM to integrate BIM with cultural heritage (Brumana et al. 2013; Khodeir et al. 2016; Oreni et al. 2013), in which a library of prototypes of parametric objects constructed from historical data, and a system for mapping parametric objects in a cloud of points and image survey data are provided (Murphy and Dore 2012; Murphy et al. 2009; Murphy et al. 2013). Most researchers have adopted a particular methodology for developing HBIM for application to historical environments and structures (Hichri et al. 2013; Huesca Tortosa et al. 2017; Murphy et al. 2013; Redmond et al. 2012; Tang et al. 2010; Wang et al. 2015). Brumana et al. (2013), conducted a case study of the church of St. Maria in Scaria d'Intelvi, Italy. Using laser scanning and photogrammetric surveys, they performed an in situ stratigraphic analysis while searching for all available historical documents, in an attempt to study the reconstruction and main transformations and chronological phases, from the Romanesque interventions, through the Baroque, to the most recent. Balderstone (2012), concluded that BIM has great potential as a means of strengthening multidisciplinary approaches to the valuation of historical assets. This study is important in that it is the first to use HBIM to determine the historical value of a monument in the country. Although technologies for digitizing monuments have previously been implemented, to the best of our knowledge, no study has combined HBIM and conventional valuation approaches.

\section{CASE STUDY: CATHEDRAL OF CHRIST THE KING}

Cathedral of Christ the King was valuated in accordance with the PT-IH Technical Procedure for valuation works that is applied to the assessment of the value of a historical property (Diario Oficial de la Federación 2009). The procedure began with inspection of the site. The land area was 13,177.23 m2, comprising a terrain with an irregular polygonal shape and an ascending and descending topography (Azcue et al. 1932). Land market exploration was then conducted. As there were no comparable activities, either in terms of 
location and area, we applied a second authorized alternative: the residual method (Diario Oficial de la Federación 2009). A topographic survey of Cathedral of Christ the King was conducted. First, the Global Positioning System (GPS) was set up and it and the subsequently obtained point cloud (details below) were linked with the National Coordinate System. This greatly facilitated the georeferencing of the survey. Next, the areas and facades of the Cathedral were scanned using high-definition surveying (HDS) with a Leica C10scanner (Leica ScanStation C10 2018). The Leica C10 scanner was used to first capture images of the scene and then laser-scan everything in its field of vision. The information produced by this scanning, called a "point cloud," consists of millions of individual 3D points. The result of the scan is a visualization of the scene in the BIM, from which any measurement can be obtained. More than 50,000 points per second were captured with millimeter precision, such that the quantification of the cathedral fabric was as precise as the technology would allow. Third, a Sokkia total station (TS) (Addison and Gaiani 2000) helped with the topographic survey. We identified the number of trees as well as their exact location and the area they occupied. Fourth, the point cloud for the upper parts, as well as the inaccessible areas, were measured using a drone with a $360^{\circ}$ camera. Then, the polygons of the cathedral were drawn in Autodesk Civil 3D, after which the images acquired by the drone were attached to further enhance the representation. A final "point cloud" was then obtained and used to complement the BIM modeling. The point cloud covered different areas with the goal of attaining a better appreciation and presentation, thus helping the visualization and the valuation of the project. Fig. 3 shows the results of the topographic survey of the cathedral.

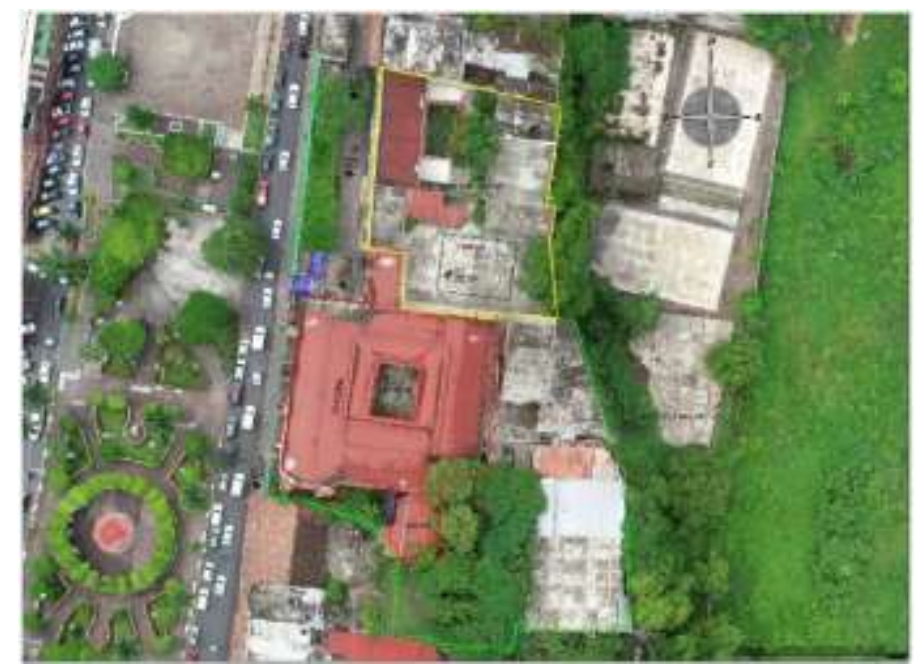

Figure 3: Topographic survey of the cathedral.

Once all the field work was complete, the collected data were uploaded to the central office for post-processing. The team performing the field work did not leave the cathedral until the central office confirmed that the uploaded data was free of errors or inconsistencies. The "point cloud" obtained in the field complemented the BIM model such that it was easier to manipulate, while realizing the possibility of creating cross-sections. The BIM 
model and "point cloud" facilitated quantification of the amount of material used in the construction of the cathedral. Thus, we were able to complete our valuation in an automated, reliable, and accurate manner.

Fig. 4 shows the cathedral modeled in Revit, based on the "point cloud."

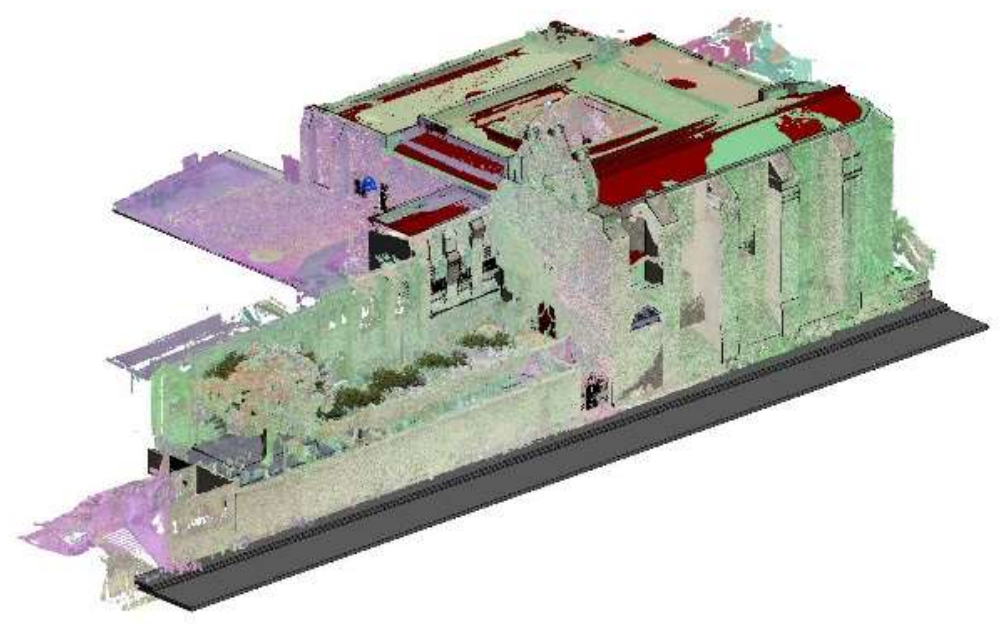

Figure 4: Image of the cathedral modeled in Revit, based on the point cloud generated with the Leica C10. More than 50,000 points per second were captured with millimeter precision.

One of the characteristics of the BIM methodology is that it is based on a technological tool (Mandujano et al. 2015). The models are parametric, so the modeling and their characteristics are intrinsically linked. Whenever the model is modified, changes are automatically generated for every aspect (Mandujano 2016). The application of BIM to the valuation proved to be extremely valuable because it is capable of detecting about 40 types of walls. The combination of the equipment used in the study allowed us to obtain information that even INAH does not possess for the cathedral, such as the thickness of the walls, and the width and shape of the mezzanines. This contribution became clear during the course of the investigation. Within the BIM model, material quantification tables were generated. These were obtained automatically and with pinpoint accuracy.

\section{RESULTS}

The land on which the cathedral stands is valued at US\$8,396,814.96 (Mandujano 2018). From the classifications of the construction of the cathedral, the volumes were quantified, to determine the corresponding unit prices. In this manner, we obtained a new replacement value (VRN). Considering the state of conservation of the property, as well as the age and functional and/or economic obsolescence, depending on the case, a demerit factor was applied to the VRN, thus giving the net replacement value of the buildings of the cathedral. The BIM model of the Cathedral of Christ the King, made in Revit, plays a crucial role in that it automatically provides the quantities of materials used in the construction. In this 
way, the VRN was obtained automatically. This saved a considerable amount of time and effort, as the BIM eliminated the need to manually tabulate all of the components of the cathedral. The total value of the construction and the complementary work was found to be US\$ 9,506,160.30. Adding the total value of the land, the construction, and the complementary work gives a total of US $\$ 17,902,975.26$. To this value must be added the historical value. A historical value analysis is proposed whereby a value can be awarded to a historical property that is in a perfect state of conservation and which has a historical, social, cultural, or religious background that is of importance to the country. To determine a heritage value factor, various data were taken as reference for the application of values such as antiquity and historical values (Diario Oficial de la Federación 2009). For the antiquity value, the property is classified according to its age, starting from a minimum of 50 years, up to greater than 400 years. The Cathedral of Christ the King was built in 1545 and is therefore more than 400 years old. When we add a percentage for the historical value and a percentage for the antiquity value, the cathedral attains a value of between $80 \%$ and $100 \%$, that is, a value of 1.76-2.00. Because the cathedral has not suffered any significant structural damage, the total value, that is, the value of the land, that of the structure, and that of the complementary works, totaling US\$17,902,975.26, is multiplied by 2.00 and the result is added to the above value. Thus, the value of Cathedral of Christ the King is US\$53,708,925.79 (Diario Oficial de la Federación 2009).

\section{DISCUSSION}

In this study, a methodology for attributing a value to the Cathedral of Christ the King was developed. The work provides a precedent for the valuation of other historical monuments through the application of both historic building information modeling (HBIM) and conventional valuation approaches. We showed that the implementation of HBIM is key to the valuation of historical monuments. The importance of HBIM and the relationship that it has with the valuation begins with the time savings that it realizes in the topographic survey, the precision with which it can be carried out, and the speed of the volumetric design. From this starting point, knowing the volume of the Cathedral of Christ the King enabled determination of the amount and type of materials with which it was built. The degree of precision of HBIM, starting with laser scanning and the creation of a "point cloud," allowed us to identify the factors that contribute to and/or detract from the value of the cathedral. This includes inherent factors of the monument itself and its location, and external factors such as street vendors, flora, fauna, noise, air, international conflicts, population growth, and economic trends. This work lays the foundations for considerable future research, in that the approval factors can be expanded within the Institute of Administration and Appraisals of National Assets (INDAABIN). By determining the external and internal factors that affect a historical monument, INDAABIN can generate new factors to generate valuations that are more precise. 


\section{CONCLUSION}

This paper described an investigation conducted in the city of Huejutla de Reyes, Hidalgo, Mexico. Mexico must be aware of the value of its assets, and be able to fully catalog every national asset, given that a country's cultural assets contribute to the identity of every citizen of that country. Cultural identity can be viewed as being both tangible and intangible. It comprises a set of values, traditions, symbols, beliefs, and modes of behavior that function as elements within a social group. Cultural identity is the sense of belonging and is a criterion contributing to differentiation. Thus, an individual can identify with some of the cultural content of a social group. Future avenues for research include the following:

- Propose Huejutla de Reyes, Hidalgo as a Pueblo Mágico (Magical Town) to the Ministry of Tourism. A Pueblo Mágico is a locality that has unique, symbolic attributes, authentic stories, transcendent facts, daily life, which means a great opportunity for tourist use, taking into account the motivations and needs of travelers (Secretaría de Turismo 2017).

- Design a control for the inventory of national assets that are held in the country as a first step in the development of a reliable plan for monuments and thus carry out interventions in the assets that most require it.

- Incorporate the travel cost method into the investigation. Using valuation techniques, economists have discovered that the economic benefits of preserving cultural resources can be substantial.

- Design new factors that will enrich the assessment proposed by INDAABIN.

- Adapt and execute the model based on the P-P-T (Mandujano et al. 2017) in order to ascertain the impact on historical assets exercised by the new factors found: internal, external, and as far as possible, find and formulate new factors.

\section{REFERENCES}

Achille, C., Lombardini, N., and Tommasi, C. (2016). "BIM and Cultural Heritage: Compatibility tests in an archaeological site." Int. J. 3-D Inf. Model. (IJ3DIM), 5(1), 29-44.

Addison, A., and Gaiani, M. (2000). "Virtualized architectural heritage: New tools and techniques." IEEE MultiMedia, 7(2), 26-31.

Alarcón, L., Mandujano, M., and Mourgues, C. (2013). "Analysis of the implementation of VDC from a lean perspective: Literature review."

Arayici, Y. (2008). "Towards building information modelling for existing structures." Struct. Surv., 26(3), 210-222.

Azcue, L., Toussaint, M., and Fernández, J. (1932). Catálogo de Construcciones Religiosas del Estado de Hidalgo, Gobierno del Estado de Hidalgo. Coordinación de Cultura, Turismo y Recreación, Hidalgo.

Balderstone, S. (2012). "Sustainable Heritage: How does it rate?" Hist. Environ., 24(2), 14.

Bedate, A., Herrero, L. C., and Sanz, J. Â. (2004). "Economic valuation of the cultural heritage: Application to four case studies in Spain." J. Cult. Herit., 5(1), 101-111. 
Brumana, R., Oreni, D., Raimondi, A., Georgopoulos, A., and Bregianni, A. "From survey to HBIM for documentation, dissemination and management of built heritage: The case study of St. Maria in Scaria d'Intelvi." Proc., Digital Heritage International Congress (DigitalHeritage), 2013, IEEE, 497-504.

Brusaporci, S. (2015). Handbook of research on emerging digital tools for architectural surveying, modeling, and representation, IGI Global.

Cameron, T. A. (1992). "Combining contingent valuation and travel cost data for the valuation of nonmarket goods." Land Econ., 302-317.

Caulkins, P. P., Bishop, R. C., and Bouwes Sr, N. W. (1986). "The travel cost model for lake recreation: A comparison of two methods for incorporating site quality and substitution effects." Am. J. Agric. Econ., 68(2), 291-297.

Choi, A. S., Ritchie, B. W., Papandrea, F., and Bennett, J. (2010). "Economic valuation of cultural heritage sites: A choice modeling approach." Tour. Managem., 31(2), 213220.

Del Giudice, M., and Osello, A. (2013). "BIM for cultural heritage." International Archives of the Photogrammetry, Rem. Sensing Spatial Inf. Sci., 5, W2.

Departamento de Turismo (2017). "Turismo: Huejutla de Reyes, Hidalgo." B. Aguiñaga, ed.Departamento de Turismo.

Diario Oficial de la Federación (2009). "PROCEDIMIENTO Técnico PT-IH para la elaboración de trabajos valuatorios que permitan dictaminar el valor de inmuebles históricos.",

$\langle$ http://dof.gob.mx/nota_detalle.php?codigo=5077210\&fecha=12/01/2009>. (2018).

Diario Oficial de la Federación (2009). "PROCEDIMIENTO Técnico PT-RES para la elaboración de trabajos valuatorios que permitan dictaminar el valor de terrenos urbanos y terrenos urbanos con construcción por el método residual.", <http://dof.gob.mx/nota_detalle.php?codigo=5079679\&fecha=06/02/2009>. (2018).

Dilnessa, A. A. (2014). "Non-Market Valuation of Cultural Heritages in Ethiopia Using Travel Cost and Contingent Valuation Methods: An Application to Rock-Hewn Churches of Lalibela." Addis Ababa University Addis Ababa, Ethiopia.

Dore, C., and Murphy, M. (2012). "Integration of historic building information modeling (HBIM) and 3D GIS for recording and managing cultural heritage sites." 18th International Conference on Virtual Systems and Multimedia, 369-376.

Fai, S., Graham, K., Duckworth, T., Wood, N., and Attar, R. "Building information modelling and heritage documentation." Proc., Proceedings of the 23rd International Symposium, International Scientific Committee for Documentation of Cultural Heritage (CIPA), Prague, Czech Republic, 12-16.

Frey, B., and Meier, S. (2006). "The economics of museums." Handbook of the Economics of Art and Culture, 1, 1017-1047.

Garagnani, S., and Manferdini, A. M. (2013). "Parametric accuracy: building information modeling process applied to the cultural heritage preservation." International Archives of the Photogrammetry, Rem. Sensing Spatial Inf. Sci., 5(1). 
Herrero Prieto, L. C., and Bedate Centeno, A. (2000). "Travel Cost Model: An application to the assesment of the historical and cultural heritage In Castile and Leon." 40th Congress of the European Regional Science Association: "European Monetary Union and Regional Policy".

Hichri, N., Stefani, C., De Luca, L., Veron, P., and Hamon, G. "From point cloud to BIM: A survey of existing approaches." Proc., XXIV International CIPA Symposium, Proceedings of the XXIV International CIPA Symposium, na.

Huesca Tortosa, J., Torregrosa Fuentes, D., Louis Cereceda, M., and Spairani-Berrio, Y. (2017). "The Façade of the Church of Nuestra Señora de la Asunción in Biar (Spain): From Point Cloud to HBIM."

Johnson, P., and Thomas, B. (1998). "The economics of museums: A research perspective." J. Cult. Econ., 22(2-3), 75-85.

Khodeir, L., Aly, D., and Tarek, S. (2016). "Integrating HBIM (Heritage Building Information Modeling) tools in the application of sustainable retrofitting of heritage buildings in Egypt." Proc. Environ. Sci., 34, 258-270.

Klamer, A., and Zuidhof, P. (1999). "The values of cultural heritage: Merging economic and cultural appraisals." Economics and Heritage Conservation. Los Angeles: Getty Conservation Institute.

Kunz, J., and Fischer, M. (2009). "Virtual design and construction: Themes, case studies and implementation suggestions." Center for Integrated Facility Engineering (CIFE), Stanford University.

Leica ScanStation C10 (2018). "El escáner láser todo en uno para cualquier aplicación." <https://w3.leicageosystems.com/downloads123/hds/hds/ScanStation\%20C10/brochuresdatasheet/Leica_ScanStation_C10_DS_es.pdf>. (2018).

Logothetis, S., Delinasiou, A., and Stylianidis, E. (2015). "Building information modelling for cultural heritage: a review." ISPRS Annals of the Photogrammetry, Rem. Sensing Spatial Inf. Sci., 2(5), 177.

Mandujano, M. (2016). "A method to identify virtual design and construction implementation strategies from a lean construction perspective." Doctorado en Ciencias de la Ingeniería Doctorado, Chile.

Mandujano, M. (2018). "Avalúo de una edificación histórica mediante la metodología del Building Information Modeling (BIM). Caso: Catedral de Cristo Rey en el municipio de Huejutla de Reyes, Hidalgo, México.", Huejutla de Reyes, Hidalgo, México.

Mandujano, M., Alarcón, L., Kunz, J., and Mourgues, C. (2015). "Use of virtual design and construction, and its inefficiencies, from a lean thinking perspective."

Mandujano, M., Alarcón, L., Kunz, J., and Mourgues, C. (2017). "Identifying waste in virtual design and construction practice from a Lean Thinking perspective." Revista de la Construcción. J. Constr., 15(3), 107-118.

Mandujano, M., Mourgues, C., Alarcón, L., and Kunz, J. (2017). "Modeling Virtual Design and Construction Implementation Strategies Considering Lean Management Impacts." Computer-Aided Civil and Infrastructure Engineering, 32(11), 930-951. 
McLoughlin, J., Kaminski, J., and Sodagar, B. (2007). Perspectives on impact, technology and strategic management, Archaeolingua.

Melstrom, R. (2013). "Valuing historic battlefields: an application of the travel cost method to three American Civil War battlefields." J. Cult. Econ.

Murphy, M., and Dore, C. "Integration of Historic Building Information Modeling (HBIM) and 3D GIS for recording and managing cultural heritage sites." Proc., Virtual Systems and Multimedia (VSMM), 2012 18th International Conference on, IEEE, 369-376.

Murphy, M., McGovern, E., and Pavia, S. (2009). "Historic building information modelling (HBIM)." Struct. Surv., 27(4), 311-327.

Murphy, M., McGovern, E., and Pavia, S. (2013). "Historic Building Information Modelling-Adding intelligence to laser and image based surveys of European classical architecture." ISPRS J. Photogramm. Remote Sens., 76, 89-102.

Nijkamp, P. (2012). "Economic valuation of cultural heritage." The Economics of Uniqueness.

Noonan, D. (2003). "Contingent valuation and cultural resources: A meta-analytic review of the literature." J. Cult. Econ., 27(3-4), 159-176.

Nypan, T. (2006). "Cultural heritage monuments and historic buildings as value generators in a post-industrial economy. With emphasis on exploring the role of the sector as economic driver. Rev."

Oreni, D., Brumana, R., Georgopoulos, A., and Cuca, B. (2013). "HBIM for conservation and management of built heritage: Towards a library of vaults and wooden bean floors." ISPRS Annals of Photogrammetry, Rem. Sensing Spatial Inf. Sci., 5, W1.

Papandrea, F. (1999). "Willingness to pay for domestic television programming." J. Cult. Econ., 23(3), 147-164.

Parumog, M., Mizokami, S., and Cal, P. (2003). "Using travel cost and contingent valuation methodologies in valuing externalities of urban road development: An application in valuing damages to cultural heritage." Journal of the Eastern Asia Society for Transportation Studies, 5(2948-2961).

Pérez, L., Barreiro, J., Álvarez-Farizo, B., and Barberán, R. (1996). "El valor de uso recreativo del Parque Nacional de Ordesa y Monte Perdido: coste de viaje versus valoración contingente." Gestión de espacios naturales. La demanda de servicios recreativos (Azqueta D., Pérez y Pérez L., eds). Mc-Graw Hill, Madrid, 173-192.

Poor, P. J., and Smith, J. M. (2004). "Travel cost analysis of a cultural heritage site: The case of historic St. Mary's City of Maryland." J. Cult. Econ., 28(3), 217-229.

Redmond, A., Hore, A., Alshawi, M., and West, R. (2012). "Exploring how information exchanges can be enhanced through Cloud BIM." Automat. Const., 24, 175-183.

Riera, P., Descalzi, C., and Ruiz, A. (1994). "El valor de los espacios de interés natural en España. Aplicación de los métodos de la valoración contingente y el coste del desplazamiento." Revista Española de Economía(ESP), 207-230.

Saygi, G., Agugiaro, G., Hamamcıoğlu-Turan, M., and Remondino, F. (2013). "Evaluation of GIS and BIM roles for the information management of historical buildings." ISPRS Ann. Photogramm. Remote Sens. Spat. Inf. Sci., 2, 283-288. 
Secretaría de Turismo (2017). "Guía de incorporación y permanencia: Pueblos mágicos." $\langle$ http://www.sectur.gob.mx/wp-content/uploads/2014/10/GUIA-FINAL.pdf $>$. (2018).

Tang, P., Huber, D., Akinci, B., Lipman, R., and Lytle, A. (2010). "Automatic reconstruction of as-built building information models from laser-scanned point clouds: A review of related techniques." Automat. Const., 19(7), 829-843.

The International Valuation Standards Committee (2006). "Exposure Draft Of Proposed International Valuation Guidance Note." International Valuation Standards Committee, London, United Kingdom, 9.

Throsby, D. (1995). "Culture, economics and sustainability." J. Cult. Econ., 19(3), 199206.

Tourkolias, C., Skiada, T., Mirasgedis, S., and Diakoulaki, D. (2015). "Application of the travel cost method for the valuation of the Poseidon temple in Sounio, Greece." $J$. Cult. Herit., 16(4), 567-574.

Wang, C., Cho, Y., and Kim, C. (2015). "Automatic BIM component extraction from point clouds of existing buildings for sustainability applications." Automat. Const., 56, 113. 